\title{
Ma-Pi 2 macrobiotic diet intervention during 21 days in adults with type 2 diabetes mellitus, Ghana 2011
} \author{
Hernández-Triana ${ }^{4}$ and Mario Pianesi ${ }^{5}$ \\ *Correspondence: mimkp2004@gmail.com

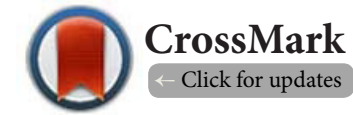 \\ 'Tamale Teaching Hospital, University for Development Studies, Ghana. \\ 2University of Ghana Medical School, Korle Bu Teaching Hospital, Ghana. \\ ${ }^{3}$ Macrobiotic Department, Finlay Institute, Havana, Cuba. \\ ${ }^{4}$ Department of Biochemistry and Physiology, Institute of Nutrition, Havana, Cuba. \\ ${ }^{5}$ UPM, A Macrobiotic Point, Italy.
}

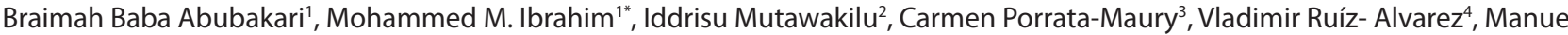

\begin{abstract}
Background: Acceptable results have been observed in Cuban, and Chinese diabetic type 2 patients treated during 21 days with Ma-Pi 2 vegetarian macrobiotic diet. The study aim was to evaluate the reproducibility of these results in Tamale, Ghana, as a part of the multicenter study promoted by UPM, A Macrobiotic Point, Italy.

Methods: A 21 day dietary intervention was carried out in 23 adult patients with type 2 diabetes mellitus. The diet consisted of whole cereals, vegetables, legumes, sesame seeds, seaweeds, soy fermented products and green tea. Patients were hospitalized during the study in the Tamale Teaching Hospital. In order to evaluate the effect of the diet, records of anthropometric measurements, body composition, biochemical indicators, blood pressure, clinical evaluation and medication adjustments, were carried out. Data at onset and at termination were compared.

Results: Despite the limitations of the intervention (small and non random selected sample, physical inactivity, and vegetable scarcities), significant reductions were recorded on: glycosemia, $47 \%$; fructosemia, $27 \%$; leukocytes, $20 \%$; blood urea, $23 \%$; and insulin consumption, $44 \%$. The urine $\mathrm{pH}$ increased by $10 \%$, which was evidence of a lower metabolic acidosis level after the diet.

Conclusions: The fast improvement of the glucose metabolic control, parallel to the significant reduction in insulin consumption evidenced the therapeutic benefit of the Ma-Pi 2 diet. These encouraging results, though preliminary, should be additionally extended in further research addressed to describe the underlying metabolic mechanisms. An additional study with a control group receiving the prescribed standard diet for type 2 diabetic patients is recommended.
\end{abstract}

Keywords: Type 2 diabetes mellitus, macrobiotic diet, ma-pi diet, therapy, adults

\section{Introduction}

The increasing prevalence of non-communicable diseases (NCDs) is a global crisis and requires a global response [1]. The 36.1 million deaths per year as a result of NCDs represent almost two of each three deaths per year worldwide; [2] 22.4 million of these deaths arise in the poorest countries, and 13.7 million in high-income and upper-middle income countries. Overall, age- specific NCD death rates are nearly two times higher in low-income and middle-income countries than in high-incomes countries [3].
NCDs are more than just a health issue, they are essential to the development of individual and improved societies [4]. Because NCDs increase poverty and are a major economic drain on individuals, families, and businesses, [5] the crisis threatens social, economic, and environmental development, and women's empowerment.

In India, the treatment cost for an individual with diabetes is $15-25 \%$ of their household earnings [6] NCDs also reduce families'resources.

The health of elderly people is of special importance in Africa

(C) 2014 Ibrahim et al; licensee Herbert Publications Ltd. This is an Open Access article distributed under the terms of Creative Commons Attribution License (http://creativecommons.org/licenses/by/3.0). This permits unrestricted use, distribution, and reproduction in any medium, provided the original work is properly cited. 
Abubakari et al. Internal Medicine Inside 2014,

because they are filling the roles of the generation decimated by HIV/AIDS. Every $10 \%$ rise in the rate of NCDs is associated with $0.5 \%$ reduction in rates of yearly economic growth [7].

Diabetes mellitus is the most frequent endocrine pathology and one of the main morbidity and mortality causes in the contemporary society. In 2008 this disease affected 347 million people worldwide, doubling their numbers in just three decades, [8] and it is estimated that over 3 million people die each year from causes related to the disease.

Between 2010 and 2030, there will be a $69 \%$ increase of adults with diabetes in the developing countries [9]. In general, data on the prevalence of diabetes in Ghana are scanty and unreliable; however diabetes prevalence studies have recorded a continuous increase. The earliest studies in the 1960 s recorded $0.2 \%$ prevalence in a population of men in Ho [10] Diabetes screening conducted by the Ghana Diabetes Association in the early 1990 s suggested $2-3 \%$ prevalence in urban areas in southern Ghana. In a later study (1998-2000) a prevalence rate of $6.4 \%$ for diabetes and $10.7 \%$ for impaired glucose tolerance (IGT) was recorded in a community in Accra $[11,12]$. A recent paper estimates an incidence rate of $4.3 \%$ in 2010 and it is expected to further increase to $5.2 \%$ in 2030 among adults aged 20-79 years in Ghanaian population [13]. On the website "Diabetes.co.uk", at least 2.2 million Ghanaians already suffer from diabetes [14].

Diet is a key factor in both prevention and treatment of type 2 diabetes mellitus. However, the conventional management of diabetic patients with severe insulin resistance is very difficult, and most of the times frustrating. Urgently, a new multifaceted approach is needed [15].

Previous dietary interventions during 21 days, with vegetarian Ma-Pi 2 macrobiotic diets in Cuban and Chinese adults with type 2 diabetes mellitus (supported by the Italian International Association UPM "A Macrobiotic Point", founded and presided by Prof. Mario Pianesi) evidenced their capacity to reduce, at short time, glycemia, serum cholesterol and triglycerides, blood pressure, and insulin consumption $[16,17]$.

Objective of this study was to prove those dietary effects at short term ( 21 days) in adults with type 2 diabetes in Ghana, as a part of the multicenter study promoted by UPM.

\section{Materials and methods}

A prospective 21 days dietary intervention study was conducted at the Tamale Teaching Hospital, Ghana, from July to August, 2011 in adults with type 2 diabetes, who used hypoglycemic medications (insulin, tablets, or both).

Initially, 25 patients were recruited according to the call for participants and accomplishment of inclusion criteria; all of them were assessed at the endocrinology clinic. Two patients were excluded during the study; one because of non fulfillment of the medical recommendation and the second person due to accidental bone fracture.

The 23 patients in the study (Table 1) used insulin Mixtard $30 \mathrm{HM}$ therapy (806 units in total; 35.0 units/patient/d) and 16 patients used hypoglycemic tablets too (metformine and glybenclamide).

\section{Ethical considerations}

The study followed the recommendations of the Declaration of Helsinki, 2000 [18]. All participants were informed about the study procedures. The patients' information was recorded in data collection sheets, and the study protocol was approved by the Scientific Councils and Ethics Committees of Ghana Health Service.

\section{Inclusion criteria}

Confirmed diagnosis of type 2 diabetes mellitus; age between 25-70years; pharmacological treatment with insulin, hypoglycemic drugs, or both; written consent of voluntary participation.

\section{Exclusion criteria}

Presence of concomitant factors able to modify the carbohydrate or lipid metabolism (e.g., illnesses, drug consumption); mental inability; addictions, and $\mathrm{BMI}<18.5$.

\section{Exit criteria}

Dietary intolerance or non acceptability of the diet; non fulfillment of the dietary or medical protocol; appearance of serious events; and voluntary abandonment of the study.

\section{Adverse events}

Any medical manifestation during the intervention, whether or not related to the diet.

\section{Intervention diet}

Vegetarian Ma-Pi 2 macrobiotic diet, $[19,20]$ designed especially by Mario Pianesi for treating diabetic patients. Total volume of the Ma-Pi 2 diet consisted of $40-50 \%$ whole grains (rice, millet and barley), 35-40\% vegetables (carrots, savoy cabbage, cabbage, chicory, onions, red radish, parsley), and $8 \%$ legumes (adzuki beans, chickpeas, lentils, black beans). As a complement we used gomasio (roasted ground sesame seeds with unrefined sea salt), fermented products (miso, tamari, umeboshi) and seaweeds (kombu, wakame, nori).

Table 1. Characteristics of the patients involved in the intervention.

\begin{tabular}{llll}
\hline Variable & Women $(\mathbf{n}=\mathbf{1 4})$ & Men $(\mathbf{n}=\mathbf{9})$ & Total $(\mathbf{n}=\mathbf{2 3})$ \\
\hline Mean age in years (range) & $50(34-58)$ & $49(25-67)$ & $50(25-67)$ \\
Average of disease evolution in years (range) & $8.1(2-19)$ & $9.2(1-24)$ & $8.6(1-24)$ \\
Mean height in cm (range) & $162.1(152.0-172.0)$ & $166.9(160.0-173.5)$ & $164.0(152.0-173.5)$ \\
\hline
\end{tabular}


Bancha tea (theine-free green tea) was the main liquid diet.

The assayed Ma-Pi 2 diet [20] is lower in energy than the traditional one recommended for diabetic patients, but safe, with adequate satiating effect due to the high fiber content, adequate in protein (12\% of the total energy), with an acceptable amino acid score, low in fat ( $15 \%$ of the total energy), and high in complex carbohydrates (73\%). The diet has a high antioxidant capacity and a high content of bioactive compounds with recognized functional properties [20] (Table 2). Foods were elaborated by culinary macrobiotic specialists from UPM, Italy, and offered at the hospital during breakfast, lunch, dinner and snacks. Unfortunately, the variety of vegetables was restricted because of limited availability.

Table 2. Average nutritional content of the Ma-Pi 2 diet offered to patients for 21 days [20].

\begin{tabular}{ll}
\hline Variable & Quantity \\
\hline Energy & $2174 \mathrm{kcal}$ \\
Protein & $66 \mathrm{~g}$ \\
Total fat & $38 \mathrm{~g}$ \\
Cholesterol & $0 \mathrm{mg}$ \\
Carbohydrates & $392 \mathrm{~g}$ \\
Fiber & $54 \mathrm{~g}$ \\
Vitamin C & $164 \mathrm{mg}$ \\
Folic acid & $751 \mu \mathrm{g}$ \\
Vitamin $\mathrm{B}_{1}$ & $3.52 \mathrm{mg}$ \\
Vitamin $\mathrm{B}_{2}$ & $1.30 \mathrm{mg}$ \\
Vitamin $\mathrm{B}_{6}$ & $5.55 \mathrm{mg}$ \\
Niacin & $25 \mathrm{mg}$ \\
Vitamin $\mathrm{B}_{12}$ & $0.45 \mathrm{mg}$ \\
Vitamin E & $10.0 \mathrm{mg}$ \\
Vitamin A & $3266 \mathrm{mg}$ \\
Potassium & $3646 \mathrm{mg}$ \\
Manganese & $16.0 \mathrm{mg}$ \\
Iron & $24.0 \mathrm{mg}$ \\
Calcium & $982 \mathrm{mg}$ \\
Phosphorus & $1632 \mathrm{mg}$ \\
Zinc & $15.4 \mathrm{mg}$ \\
Magnesium & $754 \mathrm{mg}$ \\
Sodium & $1724 \mathrm{mg}$ \\
\hline &
\end{tabular}

Patients follow up. All patients were admitted during the whole study period at the hospital, and were subjected daily to clinical evaluation (symptoms, signs, diet accomplishment, adverse events, and adjustment of medications doses) and 3 times daily to capillary blood glucose measurements (fasting, 2 hours after breakfast, and 2 hours after lunch) with a glucometer (Life Sean Inc, Johnson and Johnson, USA).

At onset and termination (after 21 days dietary intervention), the following patients' records were documented:

1. Arterial blood pressure: Measured three times a day, using an aneroid sphygmomanometer (Floor Type SB4001B, China).

2. Anthropometric measurements: body weight, body height and waist and hip circumferences were carried out by trained technicians following international recommendations [21].

Body composition was measured by bioelectrical impedance (Medisana-Benelux N.V., Italy). Primary data were used for the calculation of the Body Mass Index (BMI=weight in $\mathrm{kg} /$ height in $\mathrm{m}^{2}$ ), \% body fat and $\mathrm{kg}$ lean body mass.

3. Blood biochemical tests: The following tests were carried out after 12-hour fasting: hematological indicators, hepatic enzymes, urea, total protein, albumin, and glucose were determined in the Clinical Laboratory of the Tamale Teaching Hospital (Biotecnica Instruments, BT3000 Plus Chemistry Analyzer, USA).

Fructosamine, $\mathrm{HbA} 1 \mathrm{c}$, fasting serum insulin, C-peptide, lipid profile, folate, and serum Fe were determined in the MDS-Lancet Laboratories Ghana Ltd, in partnership with Lancet Laboratories South Africa.

Solid-phase Chemiluminiscent enzyme immunoassay on Immulite with a sensitivity of $99 \mathrm{pmol} / \mathrm{L}$ was used to measure C-peptide concentrations (normal values 99-4634 pmol/L). The ion-exchange resin separation method was used to determine $\mathrm{HbA} 1 \mathrm{c}$ levels, and a competitive radioimmunoassay based on antibody coated tubes was used to determine fasting serum insulin, with a sensitivity of $1.2 \mu \mathrm{mol} / \mathrm{L}$.

4. Urine tests: $\mathrm{pH}$ and glucose, were carried out at the Clinical Lab of Tamale Teaching Hospital.

All the determinations were carried out following international approved protocols.

Hemoglobin, total proteins, albumin, and folic acid were tested as indicators of nutritional security.

For the evaluation of the metabolic control the cut off points for diagnosis and classification of diabetes by the American Diabetes Association, 2011, were used [25].

\section{Statistical analysis}

Patients data at termination (t21) and onset (t0) were compared using the Student-or Wilcoxon tests. Because of the small sample size, the Monte Carlo simulation was used to corroborate the solidity of statistical decisions. Changes were considered significant at $\mathrm{p}<0.05$.

\section{Results}

No significant change was recorded in body weight, BMI, percentage body fat, or waist circumference. Hip circumference decreased significantly, 6\% (Table 3).

Blood glucose and fructosamine dropped significantly, $47 \%$ and $27 \%$, respectively (Table 4). Before intervention, 21 
Abubakari et al. Internal Medicine Inside 2014,

http://www.hoajonline.com/journals/pdf/2052-6954-2-3.pdf

doi: 10.7243/2052-6954-2-3

Table 3. Evolution of physical variables during the intervention, baseline data $(t 0)$ versus 21 days of diet data $(t 21)$. There was $6 \%$ decrease in Hip circumference with $p=0.013$. No significant changes were observed in the other anthropometric variables.

\begin{tabular}{lllll}
\hline Variable & $\begin{array}{l}\text { t0 } \\
\text { Mean (SD) } \\
\text { min-max value }\end{array}$ & $\begin{array}{l}\text { t21 } \\
\text { Mean }(S D) \\
\text { min-max value }\end{array}$ & $\begin{array}{l}\text { \% of } \\
\text { change }\end{array}$ & p value \\
& $\begin{array}{l}70.08(15.58) \\
\text { Weight Kg }\end{array}$ & $\begin{array}{l}70.03(15.07) \\
49.8-99.7\end{array}$ & -0.07 & 0.884 \\
& $26.20(5.85)$ & $26.07(5.68)$ & -0.49 & 0.219 \\
BMI kg/m ${ }^{2}$ & $18.75-40.25$ & $18.5-40.0$ & & \\
& $91.98(13.48)$ & $91.35(11.48)$ & -0.68 & 0.782 \\
Waist & $72-118$ & $71-110$ & & \\
circumf. cm & $95.63(14.37)$ & $89.96(7.56)$ & -5.93 & 0.013 \\
Hip circumf. cm & $75-132$ & $79-107$ & & \\
& $26.15(12.98)$ & $\begin{array}{l}25.77(11.77) \\
9.7-45\end{array}$ & -1.4 & 0.178 \\
Body Fat \% & $9.2-48.7$ & $40.10(6.33)$ & +0.03 & 0.166 \\
Lean Body Mass & $40.09(7.0)$ & $31.7-50.8$ & & \\
kg & $30.9-50.6$ & & & \\
\hline
\end{tabular}

patients showed poor metabolic control (Fructosamine $>285$ $\mu \mathrm{mol} / \mathrm{L})$; but only 16 of them after intervention. Also before intervention, 20 patients showed a glucose level higher than $6.2 \mathrm{mmol} / \mathrm{L}$; but only 9 of them still had glycemic values higher than $6.2 \mathrm{mmol} / \mathrm{L}$ at termination of the intervention. Out of 23 patients, 20 (87\%) had rapid improvement in their serum glucose level while almost all of them, 22 (96\%), had improvement in their fructosamine level (Figures 1 and 2). Glycosylated hemoglobin decreased slight-only 5\%. Fasting serum insulin and C-peptide decreased significantly, 27\% and $36 \%$, respectively (Table 4).

Mean capillary glucose dropped drastically, approaching to normal values on day 21 (Figure 3). Mean fasting glucose dropped by $47 \%, 2$ hours after breakfast $46 \%$ and 2 hours after lunch $36 \%$. Before the intervention, 9 patients showed glucose level higher than $11 \mathrm{mmol} / \mathrm{L}$ at both 2 hours post breakfast and 2 hours post lunch; however, After 21 days on the diet, only 2 and 1 patient, respectively, showed these high values.

HDL-cholesterol increased significantly by $25 \%$ during the intervention. Twenty one patients showed HDL level below $1.3 \mathrm{mmol} / \mathrm{L}$ at onset, but only 12 patients at the end of the intervention. No significant changes were observed in the rest of the serum lipids.

Blood leukocytes (as an indicator of inflammation) decreased significantly by $20 \%$. Urea decreased by $23 \%$, while alkaline phosphatase increased by $28 \%$, but within normal values. No significant changes were measured in other liver enzymes. Serum albumin and total protein also increased significantly, $12 \%$ and $10 \%$ respectively. Again, 8 patients showed albumin level below $30 \mathrm{~g} / \mathrm{L}$ at beginning of the diet intervention, and all but only 3, improved (Table 4).

In addition, urine $\mathrm{pH}$ increased significantly (10\%), and only 1 out of five patients with low urine $\mathrm{pH}$ still had urine $\mathrm{pH}$ value below 5.5. More so, the glucosuria present in 6 patients before the diet disappeared after 21 days.
Blood pressure levels showed no significant changes (Table 4).

All patients continued to use insulin; but in order to avoid hypoglycemic events, the total insulin supply had to be reduced by $44 \%$, from 806 units ( $35.0 \mathrm{u} /$ patient/d) to 455 units (19.8 $\mathrm{u} /$ patient/d). The hypoglycemic tablets quantity remained the same; only one patient abandoned it.

\section{Patient follow-up during 3 months after 21 days intensive intervention diet}

After leaving the hospital, two patients stopped using insulin as a result of well controlled glycemic values and the rest continued but with diminishing doses. Their average fasting capillary blood glucose was $7.05 \mathrm{mmol} / \mathrm{L}$. This Data indicated that the patients continued applying the principles learned in connection with the diet, and that in spite of limitations, they accomplished the therapy well enough, evidenced by the good glycemic control. This motivated the patients to continue applying the dietary guidelines.

\section{Discussion}

The short term effectiveness of the macrobiotic Ma-Pi 2 diet in the treatment of type 2 diabetes mellitus was evidenced by the fast decrease in the hyperglycemic and fructosemic values, accompanied by the drastic drop in the required amount of the hypoglycemic drugs, which points to a therapeutic independent effect of the diet. The short duration of the intervention did not allow the evidence of this effect to be reflected on the glycosylated hemoglobin.

The decrease in the high fasting serum insulin and C-peptide should be analyzed with a bit of caution, given the short duration of the intervention, and the small number of subjects with different stages of the disease and treatment with insulin.

Only a few studies have properly evidenced this short term effect of the diet alone in the context of intensive medication.

A published small study has suggested that intensive life style interventions could even be more appropriate than insulin for the improvement of glycemic control in type 2 diabetic patients with maximal level of medications [23]. Another study suggests that intensive training in health education with dietary instructions is able to improve glycemic control to such a level that they considered it appropriate to abandon the insulin therapy [24].

Recently, an intensive 6 months dietary intervention (following the nutritional recommendations of the European Association for the Study of Diabetes) carried out in 45 type 2 diabetic adults with optimal medication evidenced a significant reduction of glycosylated hemoglobin (from $8.9 \%$ to $8.4 \%$ ), body weight, BMI and waist circumference; 4 out of 14 patients reduced 81 units of insulin. The authors evaluated these modest results as significant [25]. Prospective observational studies have calculated that a $1 \%$ reduction in the glycosylated hemoglobin is associated with a $21 \%$ reduction of macrovascular and microvascular complications of type 2 diabetes [26]. 
Abubakari et al. Internal Medicine Inside 2014,

Table 4. Evolution of biochemical variables during the intervention, baseline data (t0) versus 21 days of diet data $(\mathbf{t} 21)$. All the values marked with "*” showed significant changes or improvements from their pre-intervention values.

\begin{tabular}{|c|c|c|c|c|}
\hline Variable & $\begin{array}{l}\text { to } \\
\text { Mean (SD) } \\
\text { min-max value }\end{array}$ & $\begin{array}{l}\text { t21 } \\
\text { Mean (SD) } \\
\text { min-max value }\end{array}$ & $\begin{array}{l}\% \text { of } \\
\text { change }\end{array}$ & p value \\
\hline Glucose, $\mathrm{mmol} / \mathrm{L}$ & $11.47(4.91) 5.2-22.4$ & 6.07 (1.42) 3.8-10.7 & $-47^{*}$ & 0.000 \\
\hline Fructosamine, $\mathrm{mol} / \mathrm{L}$ & 435.0 (130.6) 244-723 & $319.0(65.64) 228-502$ & $-26.6^{*}$ & 0.000 \\
\hline HbAlc, \% & 9.19 ( 2.36) 5.6-13.7 & 8.69 (1.53) 6.5-11.7 & -5.4 & 0.078 \\
\hline Fasting serum insulin, $\mu \mathrm{Iu} / \mathrm{mL}$ & $15.83(17.26) 2.9-70.1$ & $11.63(12.65) 2.2-55.8$ & $-26.5^{*}$ & 0.030 \\
\hline C-Peptide, pmol/L & $275.9(138.8) 86-546$ & $178(77.8) 59-338$ & $-35.5^{*}$ & 0.001 \\
\hline Total cholesterol, $\mathrm{mol} / \mathrm{L}$ & $3.92(1.13) 2.4-6.03$ & $4.42(0.89) 2.55-6.13$ & $+12.75^{*}$ & 0.044 \\
\hline LDL-C, mmol/L & 2.39 (1.0) $1.18-5.14$ & 2.59 (1.0) 0.34-4.84 & +8.36 & 0.331 \\
\hline HDL-C, mmol/L & $1.06(0.30) 0.6-2.1$ & $1.32(0.28) 0.91-2.02$ & $+24.52^{*}$ & 0.001 \\
\hline LDL-C/HDL-C & 2.45 (1.57) $1.18-8.57$ & $2.13(1.12) 0.19-5.32$ & -13.26 & 0.189 \\
\hline Triglycerides, $\mathrm{mmol} / \mathrm{L}$ & $1.03(0.53) 0.37-2.1$ & $1.13(0.54) 0.63-2.44$ & +9.7 & 0.602 \\
\hline Hemoglobin, g/dl & $13.41(2.07) 7.7-16.7$ & $13.37(1.83) 9.8-16.3$ & -0.29 & 0.900 \\
\hline Hematocrit, \% & 40.57 (5.71) 23.8-48.9 & 42.33 (5.18) 33.7-50.7 & +4.3 & 0.086 \\
\hline MCV, fL & $87.2(6.53) 72.8-98.4$ & $93.2(7.07) 77.4-103.8$ & $6.9^{*}$ & 0.000 \\
\hline $\mathrm{MCH}, \mathrm{pg} /$ cell & 28.69 (2.33) 22.6-32.4 & $29.31(2.35) 22.8-33.1$ & $+2.16^{*}$ & 0.000 \\
\hline MCHC, g/dL & 32.96 (1.25) 31.2-36.7 & 31.5 (1.3) 28.5-35 & $-4.43^{*}$ & 0.000 \\
\hline Serum Fe, $\mu \mathrm{mol} / \mathrm{L}$ & 13.37 (6.1) 4.5-30.4 & 14.38 (5.56) 7.6-30.2 & +7.5 & 0.318 \\
\hline Leukocytes, $10^{3} / \mathrm{mm}^{3}$ & 7.49 (2.77) 3.2-13.4 & $6.03(2.02) 3.1-11.9$ & $-19.49^{*}$ & 0.014 \\
\hline Platelets, $10^{9} / \mathrm{L}$ & 275 (119) 78-665 & 249 ( 113) 50-648 & -9.45 & 0.276 \\
\hline Folate, nmol/L & 20.33 (11.05) 6.1-45.4 & 20.53 ( 9.6) 7-45.4 & +0.98 & 0.906 \\
\hline ALAT, UI/L & 17.42 (11.62) 9.1-62.1 & 20.77 (12.1) 9.1-62.1 & +19.23 & 0.342 \\
\hline ASAT, UI/L & 19.46 (14.78) 9.4-73.5 & 22.16 (14.53) 9.8-73.5 & +13.87 & 0.525 \\
\hline GGT, UI/L & 34.98 (22.13) $15.7-102$ & 35.53 (23.77) 13.9-99.7 & +1.57 & 0.913 \\
\hline ALP, UI/L & 110.9 ) 48.4 (43.3-242.8 & 141.8 ) $33.48 .9-196$ & +27.86 & 0.008 \\
\hline Urea, $\mathrm{mmol} / \mathrm{L}$ & 4.09 ( 1.26 ) $1.52-6.91$ & $3.15(0.86) 1.59-5.22$ & $-22.98^{*}$ & 0.003 \\
\hline TP, g/L & 64.63 (7.07) 51.2-78 & 71.04 ( 4.18$) 65.6-80$ & $+9.9^{*}$ & 0.000 \\
\hline Albumin, g/L & 37.88 (5.1) 27-47 & 42.27 (3.37) 36-48 & $+11.59^{*}$ & 0.000 \\
\hline pH urine & $5.41(0.72) 5-7.5$ & $5.96(0.21) 5-6$ & $+10.17^{*}$ & 0.002 \\
\hline SBP, mmHg & 130.0 (9.05) $110-150$ & 130 (10.44) 110-160 & 0 & 1.000 \\
\hline DBP, mmHg & 80.87 (7.93) 70-100 & 79.13 (7.33) 70-90 & -2.15 & 0.406 \\
\hline
\end{tabular}

SBP: systolic blood pressure; DBP: diastolic blood pressure

In our review of literature, there is no diet proposal in which results with such a high and fast impact on carbohydrate metabolism and insulin medication have been reported, as those obtained in the present intervention and those of this multicentered UPM project previously carried out with the same Ma-Pi 2 diet in type 2 diabetic patients, either at short, $[16,17]$ medium $[27]$ or long term $[28,29]$.

The observed results in this study evidenced that the diet is the main key of an integral therapy of type 2 diabetes mellitus. These reults, even though preliminary, are very encouraging, and should be additionally extended in further research addressed to describe the underlying biochemical and physiological mechanisms. An additional study with a control group receiving the regular standard diet for type 2 diabetes is recommended.

Notwithstanding all intervention limitations (small and non random selected sample, restrictive diet and foodstuffs variety, vegetable scarcity, use of non habitual foodstuffs, physical inactivity), the observed results accomplished the fundamental goals settled down by experts in nutritional recommendations for diabetes mellitus to maintain low glycemic values or as closer to normal as possible [22]. 


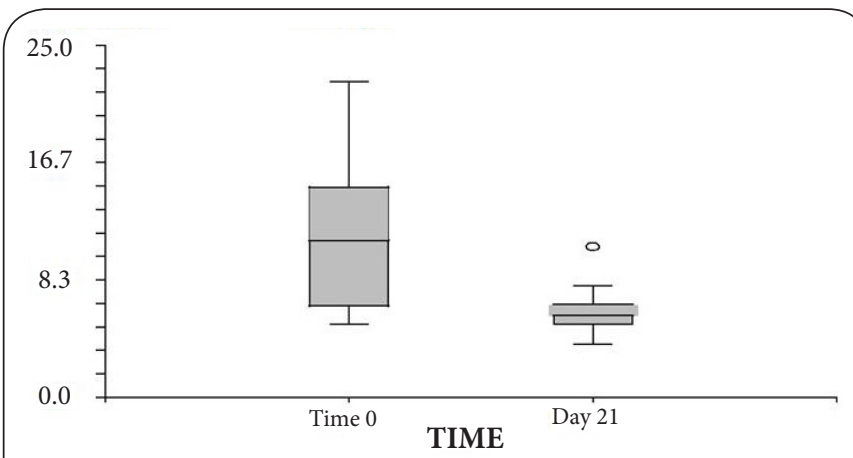

Figure 1. Evolution of the fasting glycemia during the Ma-Pi 2 diet intervention. Participants fasting blood glucose were taken before(T0) and at the termination(T21) of the intervention. Out of 23 patients, 20 (87\%) had rapid improvement in their serum glucose level over the 21 day diet intervention period.

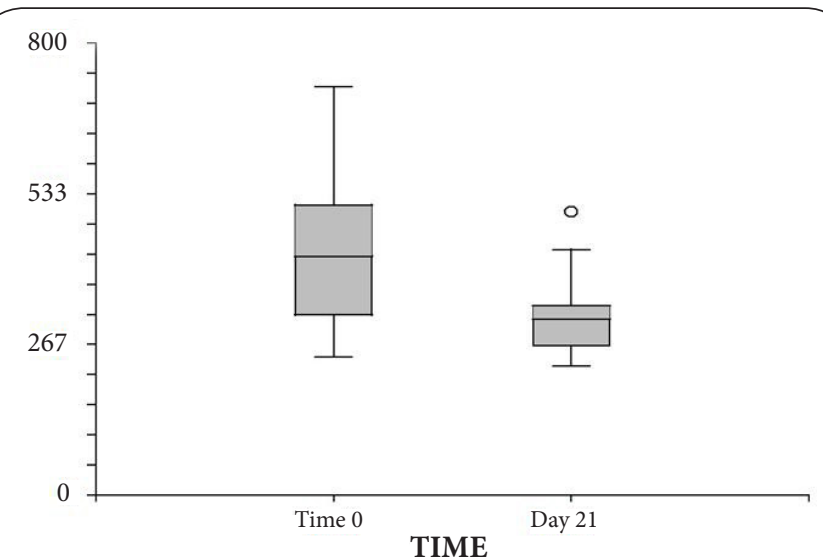

Figure 2. Evolution of the fasting glycemia during the Ma-Pi 2 diet intervention. Participants blood fructosamine levels were measured before(T0) and at the termination(T21) of the intervention. Almost all of them, 22(96\%), had improvement in their fructosamine level.

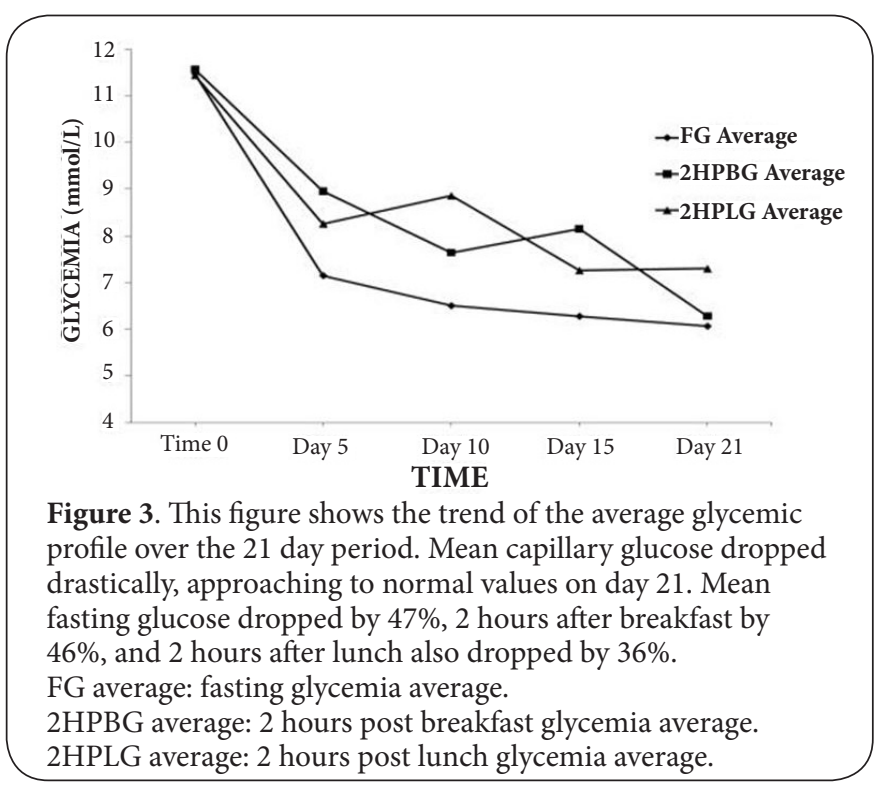

A fast control of carbohydrate metabolism was also highlighted in a recent interventional study carried out in 11 type 2 diabetic patients after 8 weeks intervention with a restrictive $600 \mathrm{kcal}$ diet. Seven of the 11 patients normalized blood glucose. In this study, the normalization of both beta cell function and hepatic insulin sensitivity was achieved by dietary energy restriction alone. This was associated with decreased pancreatic and liver triacylglycerol stores. The authors of these results concluded that the abnormalities underlying type 2 diabetes are reversible by reducing dietary energy intake [30].

We share the point of view that type 2 diabetes can be reverted with diet and life style changes. However, a better recommendation would be to obtain similar results without applying hunger diets of $600 \mathrm{kcal}$.

The impact of the diet in this study was observed despite all patients staying in their hospital beds during the whole intervention period, which favored the body weight maintenance. Only the hip circumference decreased significantly. This additional result supports the evidence of the independent quick effect of the Ma-Pi 2 diet on the carbohydrate metabolism before any obvious body weight reduction, which constitutes an appropriated therapeutic alternative for uncontrolled diabetic patients who should be institutionally treated.

Diet and physical activity are essential in the diabetes therapy, $[31,32]$ however, to increase levels of activity in patients with type 2 diabetes, an additional benefit of activity over current dietary advice would need to be clearly shown. A recent study shows, surprisingly, no additional benefits of physical activity to an intensive dietary regime, which confirms the main role of the diet on the metabolic control of diabetes [33].

Changes in dietary behavior are difficult to be monitored objectively. For this reason, the diabetic patients in this Ghana study were admitted in the Tamale Teaching Hospital and consumed their meals in their respective hospital beds. The possible negative effect of this absolute physical inactivity was anticipated. The lack of blood pressure changes in this study, as previously observed in the Cuba and China studies $[16,17]$ is perhaps related to their physical inactivity. Cuban and Chinese patients were ambulatory and showed high physical activity and energy expenditure.

Although numerous reviews on the management of type 2 diabetes have been published, $[34,35]$ practitioners are often left without a clear pathway of therapy to follow. In relation to the diet, the uncertainty is ever higher [13].

Patients from this Ghana study also showed a significant improvement in the HDL Cholesterol levels, but not in the other serum lipids. Only HDL-Cholesterol was far below normal levels before intervention. Physical inactivity could have also had a determining influence on those results.

The Ma-Pi 2 diet has a macronutrients caloric distribution very different from the one used in the above mentioned $600 \mathrm{kcal}$ caloric restriction study in which $20 \%$ of the total energy was supplied as fat, $46 \%$ as carbohydrates and $32 \%$ as proteins [30]. 
The Ma-Pi 2 diet might seem excessive in carbohydrates for diabetic patients. Although carbohydrate intake is the first determinant of the postprandial glycemic response, a great variability has been reported in the individual answers related to carbohydrate and starch type (amylose vs. amylopectin), food preparation methods (cooking procedures, heating), fasting time, pre-prandial glucose level, macronutrients distribution, insulin doses and resistance level [36].

Some studies suggest that the standard definition of macronutrients fails in capturing information of importance [37].

Most experts agree on the fact that in diabetic patients treated with insulin, the substitution of dietary carbohydrates having a high glycemic index or high glycemic load by complex carbohydrates with lower figures improves the blood glucose control and reduces the hypoglycemic episodes [38].

The whole cereal consumption in the macrobiotic Ma- $\mathrm{Pi}$ 2 diet is guaranteed by the high intake of brown rice, which shall be a key food to be considered. Brown rice, besides its nutritional rich content in dietary fiber, magnesium, zinc and manganese, contains 16 phyto compounds with recognized biological activity. It is a considerable source of fat soluble antioxidants such as phytosterols (as the gamma-oryzanol), tocopherols and tocotrienols (72-612 ppm) [39].

The Health Professionals Follow-up Study and the Nurses' Health Study I and II, conducted by the Harvard University, found that replacing $50 \mathrm{~g} / \mathrm{d}$ (uncooked, equivalent to one-third serving per day) intake of white rice with the same amount of brown rice was associated with a 16\% lower risk of type 2 diabetes, whereas the same replacement with whole grains as a group was associated with a $36 \%$ lower diabetes risk. These data support the recommendation that most carbohydrate intake should come from whole grains rather than refined grains to help prevent type 2 diabetes [40].

Another therapeutic element to consider is the absence of animal protein in the Ma-Pi 2 diet, in contrast to the high quantity consumed in the recommended diabetic diet. The modern Western diet is deficient in vegetables and fruits and contains excessive animal products, generating the accumulation of non-metabolizable anions and a lifespan state of overlooked metabolic acidosis, whose magnitude increases progressively with aging due to the physiological decline in kidney function.

High dietary acid load is more likely to result in diabetes and systemic hypertension and may increase the cardiovascular risk. Results of recent observational studies confirm an association between insulin resistance and metabolic acidosis markers, including low serum bicarbonate, high serum anion gap, hypocitraturia, and low urine $\mathrm{pH}[41,42]$. Animal protein contains sulfur-containing amino acids (methionine, homocysteine and cysteine), whose oxidation generates sulfate, a non metabolizable anion that constitutes a major determinant of the daily acid load. Persons consuming a diet based on animal protein have higher kidney net excretion and more acidic urinary $\mathrm{pH}$ than persons on a plant-based diet [43]. These aforementioned arguments explain the significant increase of the urine $\mathrm{pH}$ recorded in our study and in the previous short term study in China and the long term one in Cuba $[17,44]$.

A low fat diet rich in complex carbohydrates and dietary fiber improves the glycemic control, reduces the insulin requirements, slows down the intestinal glucose absorption, enhances the peripheral tissue insulin sensibility, and reduces body fat, arterial blood pressure, serum cholesterol and triglycerides levels [45].

The macrobiotic diets accomplish these composition requirements [20] It shall be tested if its short, medium and long term impact on the glycemic control of type 2 diabetic patients is initiated by the direct promotion of changes in the intestinal microbiota.

The epidemic of type 2 diabetes and the recognition that achieving specific glycemic goals can substantially reduce morbidity have made the effective treatment of hyperglycemia a top priority. This goal was achieved, at short time in this study, which indicates that this diet could be a valid and effective alternative for the control of the diabetes epidemic.

\section{Conclusion}

The fast improvement of the glucose metabolism, together with a significant reduction in insulin consumption, and a lower grade of metabolic acidosis after the diet evidenced the therapeutic benefit of the Ma-Pi 2 diet at short time in type 2 diabetes. These results are preliminary but encouraging and should be additionally extended in further research addressed to describing the underlying mechanisms. An additional investigation with a control group receiving the prescribed standard diet for type 2 diabetic patients is recommended.

\section{Competing interests}

The authors declare that they have no competing interests.

\section{Authors' contributions}

\begin{tabular}{|l|c|c|c|c|c|c|c|}
\hline Authors' contributions & BBA & MMI & MI & CP & VR & MH & MP \\
\hline Research concept and design & $\checkmark$ & $\checkmark$ & $\checkmark$ & $\checkmark$ & $\checkmark$ & $\checkmark$ & $\checkmark$ \\
\hline Collection and/or assembly of data & $\checkmark$ & $\checkmark$ & $\checkmark$ & -- & -- & -- & -- \\
\hline Data analysis and interpretation & $\checkmark$ & $\checkmark$ & $\checkmark$ & $\checkmark$ & $\checkmark$ & $\checkmark$ & $\checkmark$ \\
\hline Writing the article & $\checkmark$ & $\checkmark$ & -- & $\checkmark$ & $\checkmark$ & $\checkmark$ & -- \\
\hline Critical revision of the article & $\checkmark$ & $\checkmark$ & -- & $\checkmark$ & $\checkmark$ & $\checkmark$ & $\checkmark$ \\
\hline Final approval of article & $\checkmark$ & $\checkmark$ & $\checkmark$ & $\checkmark$ & $\checkmark$ & $\checkmark$ & $\checkmark$ \\
\hline Statistical analysis & $\checkmark$ & $\checkmark$ & -- & $\checkmark$ & $\checkmark$ & $\checkmark$ & -- \\
\hline
\end{tabular}

\section{Acknowledgement}

We acknowledge the contribution of the following people in conducting the research: Prosper Akanbong, Barihama Adam, Ken Sagoe, Marcellinus Kandy Welber, Juventus Ziem, Munkaila Adam, Amina Adam, Abdullai Mahmoud Thairu.

\section{Publication history}

Editor: Kent Lewandrowski, Harvard Medical School, USA.

EIC: Fabio Angeli, University of Perugia, Italy.

Received: 09-Jun-2014 Final Revised: 12-Jul-2014

Accepted: 01-Aug-2014 Published: 09-Sep-2014 
Abubakari et al. Internal Medicine Inside 2014,

http://www.hoajonline.com/journals/pdf/2052-6954-2-3.pdf

doi: 10.7243/2052-6954-2-3

\section{References}

1. Beaglehole R, Bonita R, Horton R, Adams C, Alleyne G, Asaria P, Baugh $\mathrm{V}$, Bekedam $\mathrm{H}$, Billo $\mathrm{N}$ and Casswell $\mathrm{S}$ et al. Priority actions for the noncommunicable disease crisis. Lancet. 2011; 377:1438-47. | Article | PubMed

2. WHO. Mortality and burden disease estimates for WHO Member States in 2008. Geneva. World Health Organization, 2010.

3. Stuckler D. Population causes and consequences of leading chronic diseases: a comparative analysis of prevailing explanations. Milbank $Q$. 2008; 86:273-326. | Article | PubMed Abstract | PubMed Full Text

4. United Nations high-level meeting on noncommunicable disease prevention and control. NCD summit to shape the international agenda, New York, USA. 2011. I Website

5. Suhrcke M, Rocco L, McKee M, Mazzuco S, Urban D and Steinherr A. Economic consequences of non-communicable diseases and injuries in the Russian Federation. London: European Observatory on Health Systems and Policies. 2007. I Pdf

6. Mahal A, Karan A and Engelan $M$. The economic implications of noncommunicable disease for India. Washington: World Bank, 2010. | Pdf

7. Stuckler D. Population causes and consequences of leading chronic diseases: a comparative analysis of prevailing explanations. Milbank $Q$. 2008; 86:273-326. | Article | PubMed Abstract | PubMed Full Text

8. Danaei G, Finucane MM, Lu Y, Singh GM, Cowan MJ, Paciorek CJ, Lin JK, Farzadfar F, Khang YH, Stevens GA, Rao M, Ali MK, Riley LM, Robinson $\mathrm{CA}$ and Ezzati M. National, regional, and global trends in fasting plasma glucose and diabetes prevalence since 1980: systematic analysis of health examination surveys and epidemiological studies with $\mathbf{3 7 0}$ country-years and 2.7 million participants. Lancet. 2011; 378:31-40. | Article | PubMed

9. Shaw J E, R A Sicree and PZ Zimmet. Diabetes Atlas. Global estimates of the prevalence of diabetes for $\mathbf{2 0 1 0}$ and 2030. Diab Res Clin Pract. 2010; 87:4-14. | Article

10. Dodu SRA and de Heer N. A diabetes case-finding survey in Ho, Ghana. Ghana Med J. 1964; 3:75-80.

11. Amoah AG, Owusu SK and Adjei S. Diabetes in Ghana: a community based prevalence study in Greater Accra. Diabetes Res Clin Pract. 2002; 56:197-205. | Article | PubMed

12. de-Graft Aikins A. Ghana's neglected chronic disease epidemic: a developmental challenge. Ghana Med J. 2007; 41:154-9. | PubMed Abstract | PubMed Full Text

13. Shaw JE, Sicree RA and Zimmet PZ. Global estimates of the prevalence of diabetes for 2010 and 2030. Diabetes Res Clin Pract. 2010; 87:4-14. | Article | PubMed

14. Diabetes alert in Ghana. 2007. | Website

15. Brown A, Desai M, Taneja D and Tannock LR. Managing highly insulinresistant diabetes mellitus: weight loss approaches and medical management. Postgrad Med. 2010; 122:163-71. | Article | PubMed

16. Porrata $C$, Rodríguez E, Hernández $M$, Vilá $R$, Mirabal $M$ and Díaz $M E$, et al. Risposta a breve termine all'intervento con la dieta macrobiotica Ma-Pi in 43 pazienti adulti con diabete mellito tipo 2. $7^{\circ}$ Convegno Dalle Antiche Teorie Cinesi allo Sviluppo Sostenibile Pianesiano, celebrato nell'Aula Magna, Università La Sapienza, Roma, aprile 2008, nell'ambito del "Decennio dell'Educazione allo Sviluppo Sostenibile 2005-2014. Libro degli Atti, Edizione La Pica, Urbisaglia (MC), aprile 2008, a cura di Mario Pianesi.

17. Bin W, Porrata $C, M a$ W, Xu B, Alegret $M$, Quian $Y$ and Hernández $M$, et al. Effetti a breve termine della dieta macrobiotica Ma-Pi in adulti con diabete mellito tipo 2 a Pechino. $5^{\circ}$ Convegno Ambiente-AgricolturaAlimentazione-Salute-Economia, in occasione delle Celebrazioni Ufficiali Italiane della Giornata Mondiale dell'Alimentazione, 18 ottobre 2010, Roma. Libro degli Atti, Edizione La Pica, Urbisaglia (MC), ottobre 2010, a cura di Mario Pianesi.

18. World Medical Association, Declaration Of Helsinki: Ethical Principles for Medical Research on Human Beings, General Assembly, Scotland, 52 ${ }^{\text {nd }}$ edition, 2000.
19. M. Pianesi. Le 5 diete Ma-Pi. Ediz L, Chi, Macerata, Italy, 2007.

20. C. Porrata, M. Hernández, A. Abuín, C. Campa and M. Pianesi. Caracterización y evaluación nutricional de las dietas macrobióticas MaPi. Rev Cubana Investig Biomed. 2008; 27:1-36.

21. Lohman TG, Roche AF and Martorell R. Anthropometric Standardization Reference Manual. Illinois: Human Kinetics Books Champaign; 1988. | Article

22. ADA. Diagnosis and classification of diabetes mellitus. Diabetes Care. 2011; 34 Suppl 1:S62-9. | Article | PubMed Abstract | PubMed Full Text

23. Aas AM, Bergstad I, Thorsby PM, Johannesen O, Solberg M and Birkeland $\mathrm{KI}$. An intensified lifestyle intervention programme may be superior to insulin treatment in poorly controlled Type $\mathbf{2}$ diabetic patients on oral hypoglycaemic agents: results of a feasibility study. Diabet Med. 2005; 22:316-22. | Article | PubMed

24. Goudswaard AN, Stolk RP, Zuithoff NP, de Valk HW and Rutten GE. Longterm effects of self-management education for patients with Type 2 diabetes taking maximal oral hypoglycaemic therapy: a randomized trial in primary care. Diabet Med. 2004; 21:491-6. | Article | PubMed

25. Coppell KJ, Kataoka M, Williams SM, Chisholm AW, Vorgers SM and Mann $\mathrm{Jl}$. Nutritional intervention in patients with type 2 diabetes who are hyperglycaemic despite optimised drug treatment--Lifestyle Over and Above Drugs in Diabetes (LOADD) study: randomised controlled trial. BMJ. 2010; 341:c3337. | Article | PubMed Abstract | PubMed Full Text

26. Stratton IM, Adler Al, Neil HA, Matthews DR, Manley SE, Cull CA, Hadden D, Turner RC and Holman RR. Association of glycaemia with macrovascular and microvascular complications of type 2 diabetes (UKPDS 35): prospective observational study. BMJ. 2000; 321:405-12. | Article | PubMed Abstract | PubMed Full Text

27. Kablan BJ, Kouassi D, N'Guetta KF, Adoueni KV, Kone M, Diafouka F, Boa YF, Lokrou A, Ehouman $G$ and Pianesi M. Effet curatif du regime macrobiotique Ma-Pi 2 chez le diabetique non insulinodependant (type 2) en Cote D'Ivore: resultats preliminaires. (Article submitted for publication to the Journal Cohier de Sante Publique, 2011).

28. Porrata-Maury C, Abuín-Landín A, Morales A, Vilá R, Hernández-Triana M and Menéndez $\mathrm{J}$ et al. Efecto terapéutico de la dieta macrobiótica Ma-Pi 2 en $\mathbf{2 5}$ adultos con diabetes mellitus tipo 2. Rev Cubana Invest Biomed. 2007; 26:2. | Article

29. Porrata C, Sanchez J, Correa V, Abuin A, Hernandez-Triana M, DacostaCalheiros RV, Diaz ME, Mirabal M, Cabrera E, Campa C and Pianesi M. Ma-pi 2 macrobiotic diet intervention in adults with type 2 diabetes mellitus. MEDICC Rev. 2009; 11:29-35. | PubMed

30. Lim EL, Hollingsworth KG, Aribisala BS, Chen MJ, Mathers JC and Taylor R. Reversal of type 2 diabetes: normalisation of beta cell function in association with decreased pancreas and liver triacylglycerol. Diabetologia. 2011; 54:2506-14. | Article | PubMed Abstract | PubMed Full Text

31. Nathan DM, Buse JB, Davidson MB, Ferrannini E, Holman RR, Sherwin $R$ and Zinman $B$. Medical management of hyperglycemia in type 2 diabetes: a consensus algorithm for the initiation and adjustment of therapy: a consensus statement of the American Diabetes Association and the European Association for the Study of Diabetes. Diabetes Care 2009; 32:193-203. | Article | PubMed Abstract | PubMed Full Text

32. Balducci S, Zanuso S, Nicolucci A, De Feo P, Cavallo S, Cardelli P, Fallucca $\mathrm{S}$, Alessi E, Fallucca F and Pugliese G. Effect of an intensive exercise intervention strategy on modifiable cardiovascular risk factors in subjects with type 2 diabetes mellitus: a randomized controlled trial: the Italian Diabetes and Exercise Study (IDES). Arch Intern Med. 2010; 170:1794-803. | Article | PubMed

33. Andrews RC, Cooper AR, Montgomery AA, Norcross AJ, Peters TJ, Sharp DJ, Jackson N, Fitzsimons K, Bright J, Coulman K, England CY, Gorton J, McLenaghan A, Paxton E, Polet A, Thompson C and Dayan CM. Diet or diet plus physical activity versus usual care in patients with newly diagnosed type 2 diabetes: the Early ACTID randomised controlled trial. Lancet. 2011; 378:129-39. | Article | PubMed

34. Nathan DM. Clinical practice. Initial management of glycemia in type 2 
Abubakari et al. Internal Medicine Inside 2014,

http://www.hoajonline.com/journals/pdf/2052-6954-2-3.pdf

doi: $10.7243 / 2052-6954-2-3$

diabetes mellitus. N Eng/ J Med. 2002; 347:1342-9. | Article | PubMed

35. Sheehan MT. Current therapeutic options in type 2 diabetes mellitus: a practical approach. Clin Med Res. 2003; 1:189-200. | Article | PubMed Abstract | PubMed Full Text

36. Wylie-Rosett J, Segal-Isaacson CJ and Segal-Isaacson A. Carbohydrates and increases in obesity: does the type of carbohydrate make a difference? Obes Res. 2004; 12 Suppl 2:124S-9S. I Article I PubMed

37. Colditz GA, Manson JE, Stampfer MJ, Rosner B, Willett WC and Speizer FE. Diet and risk of clinical diabetes in women. Am J Clin Nutr. 1992; 55:1018-23. | Article | PubMed

38. Willett W, Manson J and Liu S. Glycemic index, glycemic load, and risk of type 2 diabetes. Am J Clin Nutr. 2002; 76:274S-80S. I Article I PubMed

39. Sen CK, Khanna S and Roy S. Tocotrienols in health and disease: the other half of the natural vitamin E family. Mol Aspects Med. 2007; 28:692-728. | Article | PubMed Abstract | PubMed Full Text

40. Sun Q, Spiegelman D, van Dam RM, Holmes MD, Malik VS, Willett WC and $\mathrm{Hu}$ FB. White rice, brown rice, and risk of type 2 diabetes in US men and women. Arch Intern Med. 2010; 170:961-9. I Article I PubMed

41. Farwell WR and Taylor EN. Serum bicarbonate, anion gap and insulin resistance in the National Health and Nutrition Examination Survey. Diabet Med. 2008; 25:798-804. | Article | PubMed

42. Souto G, Donapetry C, Calvino J and Adeva MM. Metabolic acidosisinduced insulin resistance and cardiovascular risk. Metab Syndr Relat Disord. 2011; 9:247-53. | Article | PubMed Abstract | PubMed Full Text

43. Breslau NA, Brinkley L, Hill KD and Pak CY. Relationship of animal protein-rich diet to kidney stone formation and calcium metabolism. $J$ Clin Endocrinol Metab. 1988; 66:140-6. | Article I PubMed

44. Porrata C, Hernández M, Vilá R, Ruíz V and Pianesi M. Impatto di un intervento intensivo durante 6 mesi con dieta macrobiotica Ma-Pi 5 su adulti con diabete mellito di tipo 2 in iperglicemia nonostante fossero trattati con farmaci ipoglicemizzanti. $6^{\circ}$ Convegno "Ambiente- Agricoltura-Alimentazione-Salute-Economia" in occasione delle Celebrazioni Ufficiali Italiane della Giornata Mondiale dell' Alimentazione. Roma, 18 ottobre, 2011. Atti, Edizioni La Pica, Urbisaglia (MC), 2011, a cura di Mario Pianesi.

45. Liese AD, Roach AK, Sparks KC, Marquart L, D'Agostino RB, Jr. and Mayer-Davis EJ. Whole-grain intake and insulin sensitivity: the Insulin Resistance Atherosclerosis Study. Am J Clin Nutr. 2003; 78:965-71. | Article | PubMed

\section{Citation:}

Abubakari BB, Ibrahim MM, Mutawakilu I, PorrataMaury C, Ruíz- Alvarez V, Hernández-Triana M and Pianesi M. Ma-Pi 2 macrobiotic diet intervention during 21 days in adults with type 2 diabetes

mellitus, Ghana 2011. Intern Med Inside. 2014; 2:3. http://dx.doi.org/10.7243/2052-6954-2-3 